\title{
An ice cap landsystem for palaeoglaciological reconstructions: characterizing the Younger Dryas in western Scotland.
}

\author{
Nicholas R. Golledge (email: n.golledge@bgs.ac.uk) \\ British Geological Survey, West Mains Road, Edinburgh, EH9 3LA, UK (ph: +44 131667 1000, fx: +44 1316681535 ) \\ and School of Geosciences, University of Edinburgh, West Mains Road, Edinburgh, EH9 3JW, UK.
}

\begin{abstract}
This paper reviews the contrasting behaviours of ice caps and icefields, defines a generic landsystem model that can effectively discriminate between them, and applies the model to landform-sediment assemblages in an area of western Scotland. Such a model is necessary, since many palaeoenvironmental inferences from formerly glaciated terrains are based on the geometry, extent and dynamics of reconstructed ice masses. The validity of these glacier reconstructions is dependent on the accurate initial interpretation of relict landforms and sediments, and their inter-relationships. A new landsystems model is presented here, in which individual geological and geomorphological elements are checked against a set of eight theoretical diagnostic criteria that characterize the style of former glaciation. When applied to a $1200 \mathrm{~km}^{2}$ area of the western Scottish Highlands, the landsystem tool predicts 1) an extensive Younger Dryas ice cap with a maximum surface elevation of $900 \mathrm{~m}$ above sea level, implying colder or wetter conditions than previously thought, and 2) the survival of an independent mountain icefield in part of the area during deglaciation. Glaciological theory, proxy palaeoenvironmental data and established glacier-climate-topography relationships support these predictions, thereby giving credibility to the landsystem methodology as a generic tool for palaeoglaciological reconstructions.
\end{abstract}

KEYWORDS: Ice cap; landsystem; palaeoglaciology; reconstruction; Scotland. 


\section{Introduction}

Considerable uncertainty and debate surrounds the nature of the former ice mass that developed on the western Scottish Highlands during the Younger Dryas (12.7 - 11.3 ka, Alley, 2000) (cf Thompson, 1972; Horsfield, 1983; Thorp, 1984, 1986; Golledge \& Hubbard, 2005). The contention rests on whether the ice formed a coherent, domed ice cap (e.g. Barnes ice cap, Baffin Island; Langjökull, Iceland), or was instead a mountain icefield characterized by interconnected valley glaciers (e.g. Breheimen, Norway; Harding and Juneau icefields, Alaska). Far from being a purely semantic argument, the difference between the two forms is manifest in behavioural contrasts that impact on the palaeoclimatological inferences drawn from postulated glacier reconstructions, and on the geomorphological evolution of formerly glaciated terrain. A requirement therefore exists for a tool that allows accurate appraisal of the style of former glaciation of an area. This tool may be coupled with standard inversion modelling techniques so that the landforms and sediments used in the latter are treated in the correct glaciological context. Where possible, mapped features in a study area should be compared with those typical of different types of glacial landscape, so that the most appropriate style of glaciation may be inferred. This article defines a set of broad criteria that enable differentiation between landscapes glaciated by ice caps and those glaciated by icefields. The methodology is then applied to a study area of $1200 \mathrm{~km}^{2}$ in the western Scottish Highlands, in an attempt to resolve the existing icefield / ice cap controversy.

In order to identify the geomorphological and sedimentological criteria necessary for such a method it is important to appreciate the differences between the ice masses that produce them. Icefields and ice caps have been variably defined. Andrews et al. (1970) cite the definitions established by Ahlmann (1948), the American Geological Institute (1957), and the American Geographical Society (1958), in which icefields and ice caps are distinguished by size and by the relative relief of the ground on which they form. In their scheme an icefield covers less than $10 \mathrm{~km}^{2}$ and occupies land of high relief, whilst an ice cap is greater than $10 \mathrm{~km}^{2}$ in area and covers land of 'moderate' relief. Such definitions are rather simplistic, and their only concession to glaciological differentiation is in the assertion that ice caps flow outwards in all directions from a central area. A significantly more useful set of criteria are identified by Sugden \& John (1976). They define an icefield as an 'approximately level', non-domed ice mass whose flow is influenced by the underlying topography, and an ice cap as consisting of two components - domes, and outlet glaciers. Outward flow from the central dome by creep or basal sliding is possible even where topographic gradients are low, as a result of the great thickness of ice and high driving stresses. Underlying bedrock rises may produce muted ice-surface bumps depending on their scale. Sugden \& John (1976) emphasize 
that overlap may exist between icefield and ice cap morphology, and that the differences between a mountain icefield and a non-equilibrium ice cap may be hard to distinguish. In summarising many earlier ideas, Benn \& Evans (1998) focus on the role of topography in their definitions: an ice cap will (at least in its central area) 'submerge the landscape' and will flow independently of bed topography. In contrast, an icefield does not possess a dome-like surface and its flow is influenced by underlying topography. Again, it is recognised that there are rarely clear distinctions between types of ice mass; instead they all lie along 'spatial and temporal continuums of form'. Given a suitable climatic regime, glaciers will grow from localised corrie glaciers into a single coherent ice sheet through various intermediate forms (Figure 1A). Different magnitudes of climate change produce bifurcations in the response of ice which appear to govern whether the ice mass evolves to a stable or unstable state (Figure 1B). Ultimately these bifurcations are tempered by the nature of the underlying topography (Payne \& Sugden, 1990) (Figures 1C \& D).

FIGURE 1

There are several important glaciological and behavioural differences between thick ice caps and thinner icefields. A mountain icefield is, to a great extent, confined by topography, and will discharge towards lower ground along lines of least topographic resistance. In contrast, flow of an ice cap is governed by its surface slope, largely independent of bed topography (Glasser, 1997) (Figure 1A). The thickness and surface slope of the ice significantly influence driving stresses, which in turn: control the velocity of ice flow (Weertman, 1973; Thorp, 1991b; Mitchell, 1994); influence the thermal regime of basal ice (Glasser, 1995; Glasser \& Siegert, 2002); and in combination with the rheology and shear strength of underlying substrate, dictate the resultant mechanism of glacier flow (either internal deformation, meltwater-lubricated basal sliding, deformation of basal substrate, or a combination of all three). Ice geometry therefore significantly affects glacier dynamics, and consequently, different styles of glaciation will produce contrasting glacial landsystems (Benn \& Evans, 1998; Evans, 2003b) (Table 1). In simple terms, icefield glaciers give rise to landforms that are generally concordant with topography because they tend to flow in the direction of land surface slope, and are constrained by the valleys they occupy. Icecap margins on the other hand are significantly less affected by topography and may therefore also produce landforms whose alignments are discordant with the land surface. When positive or negative mass balance perturbs steady-state conditions, valley glacier margins expand or recede respectively, that is, they are climatically sensitive. Large ice caps may exhibit longer response times, however, partly because their often higher surface altitude and greater ice surface area (and consequent albedo) enable them to modify local climate more effectively. This may be achieved by creating greater orographic precipitation, lower surface air temperatures, and stronger katabatic winds. 


\section{The ice cap landsystem}

In order to assess the style of former glaciation in an area and ensure the most appropriate inversion model reconstruction is produced, field evidence must be compared with geomorphological and sedimentological elements that together constitute idealized icefield and ice cap 'landsystems'. The landsystem concept has been around for almost a century (cf Eyles, 1983; Evans, 2003b) and in recent years has been increasingly applied to both modern and relict glacial environments, and has become widely accepted (e.g. Andrzejewski, 2002; Evans \& Twigg, 2002; Kovanen \& Slaymaker, 2004; Clark \& Stokes, 2003; Colgan et al., 2003; Evans, 2003c; Fitzsimons, 2003; Glasser \& Hambrey, 2003; Ó Cofaigh et al., 2003; van der Wateren, 2003). In identifying areas of 'common terrain attributes' the glacial landsystem approach enables individual landform elements to be grouped into units, which when collectively linked to process-form models provide a powerful tool in palaeoglaciological reconstruction (e.g. Stokes \& Clark, 1999; Evans, 2003b). Fundamental to this method of landscape assessment is the recognition that whilst climate, bed geology and topography largely influence the formation of glacial landforms (Colgan et al., 2003), landsystem elements (and the units they make up) will also reflect both spatial and temporal differences in the behaviour of the ice mass that formed them. Thus, careful analysis of a landsystem can enable inferences to be drawn about the evolution of former ice masses, as well as their steady-state dynamics (Clark, 1997). Whilst Rea et al., (1998) and Rea \& Evans (2003) provide comprehensive summaries of plateau icefields and their diagnostic landforms, and Evans (2003a) collates detailed descriptions of many other landsystem types, a holistic view of the landform-sediment assemblages typical of ice cap landsystems is lacking. A requirement therefore exists for a set of criteria, or landsystem, that accurately defines the landforms and sediments diagnostic of ice-cap style glaciation.

TABLE 1

Given that the most apparent distinction between ice caps and icefields is in the degree of topographic control exerted on the direction of former iceflow, evidence that reflects non-topographic iceflow might be especially useful in identifying areas where ice cap glaciation has previously occurred. Such topographically unconstrained flow may be manifest in the geological record by preservation of any of the following:

1. Topographically discordant ice-marginal landforms, such as retreat moraines aligned across valleys obliquely or with their ice-contact slope on the down-valley side.

2. Areas of thick subglacial till and preservation of pre-existing deposits, particularly where ice has flowed obliquely across a valley or up a reverse slope, or across a col (Thorp, 1991a). 
In addition, the upper limit of till on steep valley sides where ice has flowed obliquely may be asymmetric, due to a predominance of lee-side cavity infilling on the up-glacier side and increased basal erosion on the down-glacier side.

3. Streamlined high-level cols where ice has overtopped local watersheds as a result of ice flow governed by surface slope rather than underlying topography. The streamlining may be evident in the presence of ice-scoured bedrock or streamlined glacigenic deposits (flutes or drumlinoid forms), or both.

4. Glaciotectonic structures and palaeo-iceflow indicators that attest to former ice flow against the topographic gradient.

5. Ice-marginal drainage where bedding suggests palaeoflow was against the modern topographic gradient, often forming ice-contact fans and resulting in ephemeral ice-marginal lakes or ponds in which laminated clay, silt and sand were deposited.

6. Streamlined and superimposed bedforms, striae, and erratic transport paths indicating predominantly radial outward ice flow from a central dome, irrespective of the trend of major valleys.

Whilst isolated occurences of the above may not be particularly instructive, their widespread presence may be diagnostic. Thus the greater the abundance and wider the distribution of such features, the stronger the case for ice cap glaciation. Where ice cap landsystem elements are either sparse or entirely absent, it can be inferred that topographic control was greater and that perhaps an icefield reconstruction is more appropriate. When a suitable reconstruction has been achieved, the overall size and geometry of the former ice mass should also be considered (Table 1).

The ice cap landsystem defined above can be regarded as a tool for palaeoglaciological reconstruction in the same manner as has been achieved elsewhere (cf Stokes \& Clark, 1999; Evans, 2003b). Comparison of empirical field evidence with landsystem elements characteristic of particular styles of glaciation enable the most glaciologically plausible explanation for landscape formation to be derived. However, since ice-mass morphologies form continuums rather than distinct and separate entities (Benn \& Evans, 1998) a degree of overlap may be expected. Additionally, it is rare for all elements of a landsystem to be present in every case (Stokes \& Clark, 1999).

Presented here are the results of detailed geomorphological and sedimentological mapping at 1:10 000 and 1:25 000 scale in an area of the western Scottish Highlands, focusing on the landsystem elements pertinent to the ice cap / icefield debate. These data form the empirical foundation for a 
palaeoglaciological reconstruction of a $1200 \mathrm{~km}^{2}$ study area, from the southern margin of Rannoch Moor at Black Mount to the head of Loch Lomond, and from Glen Lyon to Glen Orchy (Figure 2). The area is characterized by dissected mountain ranges with peaks exceeding $1000 \mathrm{~m}$ in height rising from deep valleys, the lowest of which lie almost at sea level (e.g. Loch Lomond). The area was last glaciated during the Younger Dryas , or Loch Lomond Stadial (12.7 ka - 11.3 ka, Alley, 2000).

\section{The Younger Dryas in western Scotland}

\subsection{Palaeoclimate}

The rapid, high-magnitude transition to cold conditions that characterized the onset of the Younger Dryas (Dansgaard et al., 1989; Alley, 2000; Brooks \& Birks, 2000) depressed mean temperatures by up to $8^{\circ} \mathrm{C}$ in Scotland, and produced steep west-east and south-north precipitation gradients of 40 and 50\% respectively (Clapperton, 1997; Hubbard, 1999). The climate of northwest Europe was highly unstable at this time (Witte et al., 1998), and it is likely that the UK experienced more pronounced and varied effects of this climate transition than anywhere else in the Northern Hemisphere, as a result of its maritime location and the proximity of polar water (Sissons, 1979). Snow-bearing winds from the south and south-west dominated the more vigorous atmospheric circulation of the stadial (Sissons, 1979, 1980; Ballantyne, 2002). The combination of global temperature decline with migrating precipitation fronts brought about renewed glacial and periglacial conditions in Britain, possibly rejuvenating mountain icefields that survived the Windermere Interstadial (Clapperton, 1997; Bennett \& Glasser, 1991). It is likely that glacier initiation occurred at different times in different places as a result of topographic variation, the 'snow fence effect' of mountain crests (Andrews et al., 1970; Hulton \& Sugden, 1997), precipitation differences, and the southward migration of the polar front (Sissons, 1979). Glaciers were consequently larger in the west of Scotland than in the east (Sissons et al., 1973). Using the dimensions and distribution of Younger Dryas glaciers in Scotland, Sissons (1979) calculated firn lines, which closely reflect Equilibrium Line Altitudes (ELAs), (Porter, 2001). For the Rannoch Moor area firn line altitude was approximately $600 \mathrm{~m}$ a.s.l, declining to $550 \mathrm{~m}$ a.s.l over Glen Lyon and c. 470m a.s.l over the Beinn Chabhair - Ben More massif (Figure 2). After reaching a maximal extent in c. 550 years (Hubbard, 1999), the ice mass is thought to have decayed in two phases - the first triggered by reduced precipitation, the second by rapid climatic warming (Dansgaard et al., 1989; Benn et al., 1992). Complete disappearance of the Younger Dryas ice mass by $10.6-10.4{ }^{14} \mathrm{C}$ ka BP is inferred from dated basal organic sediments on Rannoch Moor (Lowe \& Walker, 1976). 


\subsection{Style of Younger Dryas glaciation}

Recent work in part of the western Scottish Highlands has identified a mismatch between the widely accepted icefield reconstruction, largely based on the work of Thorp (1981, 1984, 1986, 1991a, b), and model predictions constrained by field evidence that suggest higher maximum icesurface altitudes typical of ice cap glaciation (Golledge \& Hubbard, 2005). These more recent findings support previous research that similarly referred to the west Highland ice mass as an ice cap (e.g. Sissons, 1979; Horsfield, 1983; Sutherland, 1984; Payne \& Sugden, 1990; Hubbard, 1999; Purves et al., 1999), but are at odds with the views of other workers who worked further to the north (Thorp, 1984, 1986; Bennett \& Boulton, 1993) or further west (Ballantyne, 2002). For any given set of parameters (such as ice temperature, bed rheology, and glacier extent) that describe (or force numerical models of) the Younger Dryas ice mass in the western Scottish Highlands, a larger volume of ice is required for an ice cap rather than an icefield reconstruction (Golledge \& Hubbard, 2005). As a result, the ice thickness in the central dome will be greater and the surface slope of the ice margins correspondingly steeper. The greater shear stress imposed by the thicker ice mass will ultimately give rise to higher strain rates and greater ice velocities (Weertman, 1973; Benn \& Evans, 1998) in the ice cap outlet glaciers than in the icefield valley glaciers reconstructed by Thorp (1991b). In order to maintain these higher balance velocities an ice cap must experience correspondingly steeper accumulation - ablation gradients, an implication which may impact significantly on palaeoclimate inferences drawn from such glaciological reconstructions.

The differences in terminology adopted by the various workers may reflect little more than the spatial and temporal variation of the ice mass in each study area, however. Those concerned with the central portion of the ice mass may find evidence typical of ice cap glaciation during its maximal extent, whilst studies focussed nearer the ice margins - on purely deglacial field evidence or on independently glaciated areas away from the main accumulation area (e.g. Benn \& Ballantyne, 2005; Benn \& Lukas, in press) - may lean more toward an icefield interpretation. In actuality, the ice mass likely evolved during its life from one form to another, leaving behind a complex geomorphological signature. The focus here is on the identification of geomorphological and sedimentological features that enable any area of a former ice mass to be critically appraised and accurately defined based on its nature at its maximal thickness and extent. 


\section{Study area}

\subsection{Existing model and previous literature}

Topography has long been recognised as a major forcing factor in glacierization (e.g. Manley, 1955; Schytt, 1967; Andrews et al., 1970; Ives et al., 1975; Payne \& Sugden, 1990; Glasser et al., 2005), and thus the degree to which the topography influences the build up and evolution of an ice mass must be regarded with at least equal import as climate. It has been suggested that the topography of the western Scottish Highlands, where high mountains surround the relatively high-altitude plateau area of Rannoch Moor, significantly influenced the style of ice mass that evolved there during the Younger Dryas (Payne \& Sugden, 1990). The study area connected the former accumulation and dispersal centre around Rannoch Moor with the southern glacier margins at Loch Lomond and Menteith, and, consequently, affected both the style and direction of former ice flow. Investigations in this area are therefore crucial to resolving ongoing differences of interpretation with regard to palaeoglaciological reconstructions.

Payne \& Sugden (1990) favoured an ice cap scenario, but other studies have been more equivocal. Mapping by Thompson (1972), Horsfield (1983), and Thorp (1984, 1986, 1987, 1991a), identified the relict glacial landforms, and to a lesser extent the sediments, of different parts of the western Highlands, and from these drew inferences about the size and dynamics of the former Younger Dryas ice mass. Thompson (1972) proposed a valley glacier reconstruction for the area around Glen Lyon, with individual glaciers sourced at altitudes $>900 \mathrm{~m}$ a.s.l. and flowing for the most part along the major valleys of the area. This interpretation was disputed by Horsfield (1983), who instead concluded that an ice cap with a maximum surface altitude of $>1000 \mathrm{~m}$ a.s.l. and centred on the Etive and Nevis mountains dominated the area. Working predominantly to the north and west of Rannoch Moor, Thorp $(1984,1986)$ found no evidence of the thick ice postulated by Horsfield (1983), but instead mapped periglacial trimlines to infer much lower ice surfaces. He reconstructed a low aspect-ratio icefield with icesheds no higher than $750 \mathrm{~m}$ a.s.l, drained by numerous fast flowing valley glaciers.

Recent research based on detailed geomorphological and sedimentological field mapping combined with numerical model predictions (Golledge \& Hubbard, 2005) produced a reconstruction whose maximum ice surface altitude contrasts significantly with that of Thorp $(1984,1986)$. This latest interpretation proposed an ice cap with a maximum surface altitude of c. $900 \mathrm{~m}$ a.s.l., and with flow in its central area largely determined by its surface slope, rather than the underlying 
topography. The ice cap dome maintained a relatively steep surface in areas up-ice of its outlet glaciers, suggesting higher basal shear stresses than those proposed by Thorp (1991b).

FIGURE 2

\subsection{New data}

The timing of glaciation in the study area is bracketed by organic deposits buried beneath subglacial till at Croftamie, southeast of Loch Lomond, suggesting a maximum glacier extent at 10, $560 \pm 160{ }^{14} \mathrm{C}$ ka BP, (Evans \& Rose 2003), and inferred ice-free conditions on Rannoch Moor by $10,660 \pm 240-10,390 \pm 200{ }^{14} \mathrm{C}$ ka BP, (Lowe \& Walker, 1976). Although the dates from Rannoch Moor may be 'too old' (Sissons, 1979), the Croftamie dates nonetheless imply that the Younger Dryas ice reached its maximum southerly extent very late in the Stadial, and that subsequent deglaciation was very rapid indeed.

Landforms and sediments in the northern sector of the study area (Figure 2) have been described elsewhere (Golledge \& Hubbard, 2005), and consequently are only summarised here. There is a marked within-valley asymmetry in the distribution of moraines in the northern sector, unrelated to differential rockfall input (sensu Benn, 1989), and in many cases the moraines are aligned obliquely across valley floors. Thick accumulations of subglacial till are preserved only in localities where ice flowed against the topographic gradient; within-valley asymmetry of till cover is particularly prominent in e.g. glens Lochy and Lyon. A number of high-level (> $700 \mathrm{~m}$ a.s.l) cols show evidence of glacial streamlining indicative of transfluent ice flow, and glaciotectonic structures and sedimentary bedding in glaciofluvial sediments are consistent with radial iceflow from Rannoch Moor. Striae, roches moutonnée and erratic carry also indicate non-topographically constrained iceflow in a broadly radial pattern consistent with a major iceshed to the northwest.

Recent mapping south and west of this area has identified abundant ice-marginal landforms (predominantly moraines), for example in Cononish Glen where they trend obliquely across the valley sides and valley floor, that is, generally discordant to the local topographic slope. Two large lateral moraines steeply descend the hillsope at the western end of the glen (Figure 3 A, B) and are aligned with valley-floor moraines to form cross-valley ice-marginal assemblages. There is a high density of moraines in much of Cononish Glen, and many of the individual diamicton and sand and gravel-composed mounds are 5-10 m in height with complex internal stratification. Some areas of the glen, however, are devoid of moraines. Neighbouring Glen Auchreoch hosts numerous morainic ridges that, although concordant with topography in terms of their cross-valley 
alignments, display steep ice-contact slopes on their northern (down-valley) sides. Sections in the moraines prove their composition to be stratified ice-contact debris flows and bedded sand and gravel, a characteristic of Younger Dryas moraines elsewhere in Scotland (Lukas, 2005; Benn \& Lukas, in press). Another high-density area of topographically discordant moraines exists in Lairig an Lochain (Figure 2) where the ice-marginal landforms (moraines and associated meltwater channels) form sub-parallel linear assemblages descending obliquely across the valley floor. The most abundant moraines in the study area, however, occur in the undulating plateau area south of the Ben Lui - Beinn Dubhchraig watershed (Figure 2). Here a sub-parallel assemblage of broad moraine ridges trend approximately west-east in an arcuate belt $2-3 \mathrm{~km}$ wide at a height of 350 - 550m a.s.l. Many of these ridges are overprinted with approximately north-south aligned lineations, or show evidence of remoulding (Figure 4). The larger, 'parent', moraines undergo a transition up to $700 \mathrm{~m}$ a.s.l into bedrock ridges of the same orientation.

\section{FIGURE 3}

Distribution of till in this central area is highly variable both in spatial extent and in terms of its thickness. Many of the valleys (e.g. upper Glen Orchy) have only thin valley-floor till cover, whereas others (e.g. Coire Chailein, Coire Thoin, Coire Bhiocair, Glen Auchreoch) host till accumulations up to $35 \mathrm{~m}$ thick. In Coire Chailein, Coire Thoin and Gleann nan Caorann a distinct cross-valley asymmetry of infill is apparent. In these valleys, till occurs significantly higher on one side of the valley than the other. Complex stratigraphies are present in the Coire Chailein and Coire Thoin valley infills, representing more than one period of sediment deposition. In Coire Chailein c. $6 \mathrm{~m}$ disturbed but bedded gravel, sand, silt and clay separates a $13 \mathrm{~m}$ thick lower sand-dominated yellow-brown till from an upper $8 \mathrm{~m}$ thick silt- and clay-dominated grey and brown till. In Coire Thoin the grey till abruptly overlies a reddish sandy diamicton that when subjected to X-Ray Diffraction (XRD) analysis yielded a strong peak consistent with the presence of kaolinite, a clay mineral weathering product whose abundance in a deposit increases with age.

Streamlined high-level cols in this central area attest to the prevalence of transfluent ice in many areas. Transfluent flow is indicated by ice-smoothed cols south of Ben Challum (650m), and between Ben Lui and Ben Oss (690m), (Figure 2). In these cases glacial streamlining is manifest as ice-smoothed bedrock with few loose frost-shattered surface blocks. Elsewhere, streamlined cols host drumlinoid ridges or flutes (e.g. around Coir' Orain and above Coire Chailein). These ridges are variably composed of diamicton, boulders, and / or disaggregated bedrock, and in most cases range in height from $2-5 \mathrm{~m}$. Deformed sedimentary structures preserved in a $1 \mathrm{~m}$ thick 
sand, silt and clay unit in Coire Chailein resemble a sheath fold, which, when carefully dug out, showed southerly vergence (Figure $3 \mathrm{C}, \mathrm{D}$ ). Elsewhere, minor silt and sand units within or associated with moraines often show glaciotectonic folding or faulting. Exposures in Cononish Glen and Gleann Auchreoch reveal abundant evidence of post-depositional sediment deformation (folding and faulting) typical of actively oscillating ice margins. The vergence of these deformation structures is shown in Figure 2. Evidence of non-topographically directed sub-aerial deposition of bedded sand and gravel at former ice margins is preserved in the central sector of the study area in e.g. Coire Thoraidh and Cononish Glen. Exposures on the lee side of a moraine in Coire Thoraidh proved steeply southwestward-dipping foreset-type beds of alternating sand, gravel and diamicton. In Glen Cononish, well-sorted sand beds flanking a low moraine exhibited an approximately $10^{\circ}$ west-northwestwards dip; counter to the local topographic slope. Also in Glen Cononish proglacial sand and gravel outwash was recorded dipping southward into the hillslope below Ben Oss.

Patterns of former high-level iceflow can be inferred from erratic transport paths. Southerly iceflow across a NW-SE aligned mafic dyke crossing the summit ridge of Fiarach (Figure 2) produced long erratic trains $(>1 \mathrm{~km})$ along the wide summit ridge to the south-southwest. Sub-rounded boulders of coarse-grained granite up to $2 \mathrm{~m}$ diameter were recorded on moraines south of $\mathrm{Fi}$ arach, below Cruachan Cruinn col (492m). Granite is found in situ only to the north, underlying Rannoch Moor, and to the southwest from the head of Glen Fyne to Garabal Hill. Metalimestone erratics from the southern flanks of Ben Oss also show generally southerly transport across the wide plateau.

FIGURE 4

South of Glens Dochart and Falloch, the Ben More - Ben Chabhair massif hosts a landformsediment assemblage that contrasts distinctly with those described above. Moraines in this area are numerous but generally restricted to valley floors and lower hillslopes. At the northern end of Coire a' Chuilinn (Figure 2) latero-frontal moraine ridges arc across the valley, indicating that ice lay to their southeast. The ridges are typically $<10 \mathrm{~m}$ high and fragmentary. At the northwest end of Coire Andoran is a $>10 \mathrm{~m}$ high morainic bank composed of stratified debris-flow diamictons and capped with southwest-dipping cross-bedded sand and gravel ( $>1 \mathrm{~m}$ thick). Few other features were observed further south. Topographically concordant, low, arcuate, bouldery spreads and cross-valley moraines also occur along the length of Coire Earb, indicative of active south-southeastward ice margin recession. Many of the moraine crests are strewn with angular blocks of local metasedimentary lithologies $2-5 \mathrm{~m}$ diameter. On the southern side of the massif, topographically-concordant cross-valley moraines occur in Balquhidder Glen and Ishag Glen (Fig- 
ure 2). Thick till was mapped in limited parts of Balquhidder Glen but in none of the tributary valleys, and no asymmetry in valley-side till cover was observed. Rather, many of the glens showed a notable absence of till on all but the lowest slopes (e.g. Coire a' Chuilinn and Coire Andoran). The floors of these glens, particularly in their upper reaches, are dominated instead by ice-scoured bedrock and ubiquitous locally derived, angular, rockfall boulders.

Ice-smoothed bedrock is abundant at higher altitudes across the massif, but can be misidentified due to the naturally smooth mica-rich sub-horizontal metasedimentary bedding planes. Distinction can be based instead on the relative abundance of frost-shattered surface debris, or where smoothing contrasts can be identified within the same lithology over small areas. Northeast of Cruach Ardrain for example, ice-smoothed rock occurs up to $930 \mathrm{~m}$ but no higher. The north flank of Ben More exhibits a vertical transition to fractured, frost-shattered rock around $860 \mathrm{~m}$; the $862 \mathrm{~m} \mathrm{col}$ and rock surfaces up to $930 \mathrm{~m}$ between Ben More and Stob Binnein are similarly smoothed, but their summits at $1174 \mathrm{~m}$ and $1165 \mathrm{~m}$, respectively, exhibit thin regolith mantles over frost-shattered bedrock. No glaciotectonic deformation was observed in sediments in the southern area. However, clear evidence of topographically concordant ice-marginal drainage exists in Coire Earb where a flat-topped, gently northwest-dipping (down-valley) terrace is preserved (Figure 3 E, F). The up-valley margin of the terrace is contiguous with a well-developed cross-valley moraine, and a section in the distal end proved it to be composed of bedded sand and laminated silt. Its location in the middle of the valley floor, but significantly higher than any fluvial terraces in the glen, suggests that the terrace may have a glaciodeltaic origin.

In summary, the landsystem elements in the northern and central sectors of the study area comprise moraines aligned obliquely across valleys; preservation of older deposits and localised thick accumulations of till; streamlined high-level cols; and glaciotectonic and ice-marginal sedimentary structures indicative of non-topographically controlled ice and meltwater flow. By contrast, landsystem elements in the southern area indicate topographically concordant moraines; limited till deposition; bedrock smoothing at variable altitudes and ice-marginal meltwater flow that was governed primarily by topographic slope.

\section{$5 \quad$ Testing the landsystem model}

The above examples illustrate that a variety of landform-sediment assemblages are present in the study area of the western Scottish Highlands. By comparing the distribution and abundance 
of individual landsystem elements with the theoretical criteria defined above an assessment of dominant glaciation style can be made for each sector of the study area (Table 2).

TABLE 2

It is apparent that whilst the northern and central areas exhibit key similarities, the southern sector is markedly different. The maximum altitude of widespread streamlined bedrock decreases southward and southeastward from Rannoch Moor but rises abruptly south of Glen Falloch. Thick till accumulations and preserved sedimentary sequences are present north of Glen Falloch but absent further south. Deglacial landsystem elements such as moraines and ice-marginal glaciofluvial sediments reflect non-topographic large-scale radial ice flow in the northern and central sectors of the study area, whilst those in the southern sector are topographically-concordant and show only small-scale radial ice flow. On the basis of the landsystem evidence it is therefore proposed that the northern and central sectors were overwhelmed during the Younger Dryas by an ice cap flowing radially from Rannoch Moor and the surrounding mountains. During deglaciation the ice cap thinned and retreated actively back to its source area, maintaining margins steep enough in some areas to form topographically discordant landsystem elements. By contrast, the mountains in the southern sector may have acted as a subsidiary accumulation centre of the ice cap at maximum extent, which separated from the main ice cap during deglaciation and survived as a mountain icefield feeding topographically constrained outlet glaciers. This hypothesis can be tested by theoretical reconstruction of the former ice surface.

Field mapping has already enabled accurate constraint to be placed on the upper limit of ice in the northern sector of the study area (Golledge \& Hubbard, 2005). The same methodology is adopted for the central and southern sectors, enabling ice surface contours to be constructed along flowlines based on the empirical data and constrained by equations for theoretical parabolic profiles (Nye, 1952; Paterson, 2000). The overall geometry of the ice mass between flowlines is then approximated and guided by previous reconstructions (e.g. Horsfield, 1983) (Figure 5). Digitised ice-surface contours were used to generate a triangulated ice cap surface using ArcGIS 9.0, from which a 3D surface grid was interpolated. Raster subtraction of the topographic surface from the ice cap grid allowed ice thicknesses and the location of nunataks to be checked quickly and accurately. These methods also allow basal shear stresses to be calculated, using:

$$
\tau=\rho g h \sin \alpha
$$

where $\rho$ is the ice density $\left(900 \mathrm{~kg} \mathrm{~m}^{-3}\right), g$ is gravitational acceleration $\left(9.81 \mathrm{~m} \mathrm{sec}^{-2}\right), h$ represents 
ice thickness (m), and $\alpha$ is the ice surface slope (Paterson, 2000). Applying Equation (1) to centre points of Glen Orchy, Glen Falloch / Loch Lomond, and Glen Lyon yields, respectively, values of $\tau=30-50 \mathrm{kPa} ; 45-60 \mathrm{kPa} ; 50-80 \mathrm{kPa}$.

FIGURE 5

Importantly, the feasibility of the local ice centre in the southern sector can be tested using the summit breadth vs height relationship defined by Manley (1955). The curve defines the non-linear inverse relationship between mountain or plateau summit breadth and the height above the firn line (or ELA) at which snow can be expected to accumulate. When the breadths of major summits in the Beinn Chabhair - Ben More massif are plotted against height relative to the local ELA (435-505m a.s.l., Sissons, 1979), five of the seven summits could theoretically support snow accumulation during the Younger Dryas (Figure 6). Geomorphological evidence indicates, however, that whilst many of the summits may have accumulated snow, their ice-cover was probably thin, cold-based and non-erosive (cf Kleman, 1994; Rea et al., 1998; Rea \& Evans 2003). Nonetheless, the concordant moraines and glaciodeltaic sediments suggest that accumulation on these summits was at least sufficient to nourish a local mountain icefield which remained active following recession of the Rannoch Moor ice cap.

The sensitivity of this mountain icefield to climatic changes typical of a warming deglacial environment can be tested by using a number of palaeoclimatic parameters and proxies. Air temperatures in Scotland during the Late-glacial have been inferred from palaeoecological data c. $170 \mathrm{~km}$ southeast of the study area (Brooks \& Birks, 2000), which, when corrected for sea-level, indicate a mean summer air temperature of $8.5^{\circ} \mathrm{C}$ during the Younger Dryas. Use of this proxy seems appropriate, given that present sea-level mean summer temperatures in the two areas are almost identical (c. $\left.14^{\circ} \mathrm{C}\right)$. Palaeo-precipitation values can be calculated from this using the global ELA temperature and accumulation data presented by Ohmura et al. (1992), which yield the following linear regression equation $\left(\mathrm{R}^{2}=0.81\right)$ :

$$
a=(t+0.9419) / 0.0024
$$

in which $a$ is the total annual accumulation, and $t$ is the mean summer air temperature, at the ELA. Using an altitudinal lapse rate of $0.68^{\circ} \mathrm{C} / 100 \mathrm{~m}$ to derive $t$ from the sea-level temperature above, Equation (2) predicts a likely accumulation at the ELA of $2364 \mathrm{~mm} \mathrm{a}^{-1}$, implying former mean annual precipitation (MAP) of $3547 \mathrm{~mm} \mathrm{a}^{-1}$ (Ballantyne 2002). Deglaciation would only begin to affect accumulation on this massif after a rise in local ELA of approximately $65 \mathrm{~m}$, which 
equates to a rise in mean annual ELA air temperature of $0.44^{\circ} \mathrm{C}$ or a drop in annual precipitation of approximately $130 \mathrm{~mm} \mathrm{a}^{-1}$. A temperature rise of $1.15^{\circ} \mathrm{C}$ and $1.31^{\circ} \mathrm{C}$ at the ELAs of the highest and broadest summits (Ben More and Beinn a' Chroin), or net decreases in annual precipitation of 331 and $403 \mathrm{~mm} \mathrm{a}^{-1}$ respectively, would suppress effective accumulation.

FIGURE 6

\section{Discussion}

Landform-sediment assemblages diagnostic of ice cap glaciation have been defined above (Table 1). By using the alignment of former moraines, the distribution of thick till sequences, the altitudes of streamlined cols, kinematic indicators such as glaciotectonic structures, and the direction of flow of ice-marginal outwash, it has been possible to reconstruct the style of Younger Dryas palaeo-iceflow in part of the western Scottish Highlands (Figure 5). This empirical reconstruction is constrained by published maximal limits and overall ice-mass geometries (Sissons, 1979; Horsfield, 1983; Thorp, 1984, 1986; Hubbard, 1999) and is supported by theoretical ice surface profile calculations (Nye, 1952; Paterson, 2000) and established accumulation area / altitude relationships (Manley, 1955; Rea et al., 1998). The reconstruction shows that ice flowing radially from Rannoch Moor overwhelmed many of the high-level cols between mountains to the southeast, and many of the hills to the south and southwest (Figure 5). Transects from south of the Rannoch Moor source area to 3 main outlet glaciers are shown in Figure 7. These cross-sections demonstrate the variable degree of topographic control exerted on the ice cap in this study area. Significantly, ice surfaces projected from the maximal ice height of c. $700 \mathrm{~m}$ a.s.l. proposed by Thorp $(1984,1986)$ show that the ice would have been constrained by bed topography to a much greater degree, consequently giving rise to a very different style of glaciation and landsystem. In the new reconstruction, flow is concordant with the underlying topography in areas where bed slope and ice surface slope were similar, but discordant where the two differed. Where the latter is true, former ice flow was governed primarily by the direction of ice cap surface slope.

Where soft-bedded outlet glaciers drained the central dome, such as in Loch Lomond and Glen Dochart, decreased basal drag enabled lowering of the ice surface. Steeper ice surface gradients at the heads of these outlets no doubt propagated greater strain heating of the drawn-down ice, and enabled faster flow through a combination of bed deformation and basal sliding. The coincidence of these drawdown zones with areas of streamlined, remoulded or superimposed bedforms (Figures $2 \& 4)$ suggests that formation of such features was largely controlled by the occurence of these 
particular glaciological conditions.

FIGURE 7

South of Glen Falloch and Glen Dochart a local dome in the main ice cap is inferred; one that thinned during deglaciation to a climatically sensitive mountain icefield whose outlet glaciers were confluent with the retreating ice cap margin in Glen Falloch. Independent centres such as this are known to have existed elsewhere in Scotland during the Younger Dryas (Sissons et al., 1973; Lukas, 2005; Benn \& Ballantyne, 2005). The local dome on the Beinn Chabhair - Ben More massif deflected south-flowing ice southwestward through Glen Falloch, and contributed to eastward iceflow through Balquhidder Glen. Much of the ice forming the Loch Lomond glacier was probably sourced in the high plateau area south of Ben Lui and Ben Oss, a factor that no doubt enabled greater southerly extension of the ice cap than could otherwise have been achieved. The new reconstruction may also call into question the eastern limit of ice in Glen Lyon, proposed by Thompson (1972) to lie at Innerwick (Figure 2 inset). For this to be the case the ice-surface gradient in this area would have had to have been especially steep, falling c. $600 \mathrm{~m}$ in less than $10 \mathrm{~km}$. Instead it is preferable to invoke a staged recession of the ice cap (Figure 8), perhaps as windward migration of the ice divide led to overall thinning and early retreat of eastern margins, as seen, for example, in Patagonia (e.g. Sugden et al., 2002).

\section{FIGURE 8}

The patchy and generally thin subglacial till in the study area shows that, in general, bed deformation played only a limited role in glacier motion. Instead, ice flow in the central area of the ice cap was probably accomodated through a combination of basal sliding and internal deformation. Basal shear stresses in the Loch Lomond and Glen Lyon outlet glaciers were of the order $45-60 \mathrm{kPa}$ and $50-80 \mathrm{kPa}$ respectively - slightly higher than the values of $40 \mathrm{kPa}$ and $53 \mathrm{kPa}$ calculated by Thorp (1991b). Higher stresses are consistent with the steeper ice cap profile predicted here. The new reconstruction implies greater net accumulation than necessary in Thorp's (1984, 1986) model, suggesting either greater palaeo-precipitation, lower summer palaeo-temperatures, or both. Many Scottish studies have attempted to link palaeoglaciological reconstructions of individual glaciers or icefields with climate (e.g. Sissons, 1979; Ballantyne, 1989; Benn et al., 1992, Ballantyne, 2002), but significant problems are known to exist in applying such an approach to larger areas, due to the complex and non-linear response of ice masses to climate fluctuations (Kerr, 1993; Purves \& Hulton, 2000; Sugden et al., 2002). The link between ELA and climate is well established (Sutherland, 1984; Benn \& Lehmkuhl, 2000), but misinterpretation of the style of glaciation is a key source of error in the determination of ELAs and the palaeoclimatic inferences drawn from 
them (Rea et al., 1998). Additionally, any reconstruction, including that presented here, can only offer a 'snapshot' of the ice cap during its dynamic evolution. It may be postulated therefore that the periglacial trimlines used to determine former ice-surface altitudes (e.g. Thorp, 1981, 1984) represent later 'snapshots' in the time-transgressive fluctuations of the ice cap's lateral margins. A possible reconciliation of the differing interpretations might thus rest on the exact chronology of formation of each landsystem element. Early growth of a thick, relatively immobile, ice cap that overwhelmed much of the area south and southeast of Rannoch Moor may have been followed by a period of dynamic drawdown that led to thinning and ice surface lowering. Greater temperature fluctuations in this period of unstable climate may have promoted aggressive freeze-thaw processes that shattered newly exposed, glacially-weakened rock surfaces. Lithological contrasts governing bedrock strength controlled the efficacy of these processes, thus giving rise to spatial variability in the development of trimlines. Accelerating flow of outlet glaciers at this time may have enabled their maximal southerly limits to be reached late in the Stadial, before irreversible negative mass balance led to rapid recession of ice margins and widespread deglaciation.

\section{Conclusions}

This article defines a set of eight physical, geomorphological and sedimentological criteria for the identification of non-topographically confined ice flow, allowing landform-sediment assemblages to be treated as elements of a larger landsystem. This ice cap landsystem, characterized here for the first time, sets forth diagnostic criteria that can be used together as a generic tool in determining the nature of a former ice mass in any relict glacial landscape.

In this study of part of the western Scottish Highlands, the field evidence in much of the area satisfies the eight key criteria indicative of ice cap-style glaciation: a reconstructed ice cap greater than $1000 \mathrm{~km}^{2}$, a low domed centre feeding outlet glaciers, topographically discordant moraine alignments, preservation of thick valley-floor sediment infills, streamlined high-level cols, countertopographic iceflow indicators and ice-marginal drainage, and collective wider evidence of radial outflow from the central dome. Only in the south of the study area does the field evidence indicate topographically confined ice flow. The former presence of a subsidiary but coalescent ice cap dome is inferred, which downwasted to a climatically sensitive mountain icefield feeding discrete outlet glaciers.

Together, these elements strongly suggest that the ice-mass in the western Scottish Highlands 
was largely unconstrained by topography during Younger Dryas maximum but became progressively more so during deglaciation. This interpretation is supported by good agreement with numerical reconstructions (Hubbard, 1999) and is based on physical glaciological principals (Nye, 1952; Paterson, 2000), palaeoecological climate-proxy data (Brooks \& Birks, 2000) and established glacier - climate (Ohmura et al., 1992) and glacier - topography (Manley, 1955) relationships. This new reconstruction implies greater accumulation than previously envisaged, perhaps reflecting a wetter or colder Younger Dryas climate.

\section{Acknowledgements}

I am very grateful to Tom Bradwell, Martyn Stoker and David Sugden for constructive comments on earlier manuscripts, and to Elizabeth Pickett for observations in the field. Dave Evans and Matthew Bennett provided constructive reviews that improved the work. The paper is published with permission of the Executive Director of the British Geological Survey, NERC.

\section{References}

Ahlmann, H.W., 1948. Glaciological research on the North Atlantic coasts. Royal Geographical Society Research Series, 1. Royal Geographical Society, London.

Alley, R., 2000 The Younger Dryas cold interval as viewed from central Greenland. Quaternary Science Reviews 19, p213-226.

American Geographical Society, 1958. Geographic study of mountain glaciation in the northern hemisphere. Department of Exploration and Field Research, contract DA19-129-QM-409. Part 1. American Geographical Society, New York.

American Geological Institute, 1957. Glossary of geology and related sciences. Publication 501. American Geological Institute, Washington D.C.

Andrews, J.T., Barry, R.G., Drapier, L., 1970. An inventory of the present and past glacierization of Home Bay and Okoa Bay, east Baffin Island, N.W.T., Canada, and some climatic and palaeoclimatic considerations. Journal of Glaciology 9, p337-362.

Andrzejewski, L., 2002. The impact of surges on the ice-marginal landsystem of Tungnaárjókull, Iceland. Sedimentary Geology 149, 59-72.

Ballantyne, C.K., 1989. The Loch Lomond Readvance on the Isle of Skye, Scotland: glacier reconstruction and palaeoclimatic implications. Journal of Quaternary Science 4, 95-108.

Ballantyne, C.K., 2002. The Loch Lomond Readvance on the Isle of Mull, Scotland: glacier 
reconstruction and palaeoclimatic implications. Journal of Quaternary Science 17, 759-771.

Benn, D.I., 1989. Debris transport by Loch Lomond Readvance glaciers in Northern Scotland: basin form and the within-valley asymmetry of lateral moraines. Journal of Quaternary Science 4, 243-254.

Benn, D.I., Ballantyne, C.K., 2005. Palaeoclimatic reconstruction from Loch Lomond Readvance glaciers in the West Drumochter Hills, Scotland. Journal of Quaternary Science 20, 577-592.

Benn, D.I., Evans, D.J.A., 1998. Glaciers and Glaciation. Arnold, London.

Benn, D.I., Lehmkuhl, F., 2000. Mass balance and equilibrium-line altitudes of glaciers in high-mountain environments. Quaternary International 65/66, 15-29.

Benn D.I., Lukas S., in press. Younger Dryas glacial landsystems in western Scotland: possible modern analogues and palaeoclimatic implications. Quaternary Science Reviews.

doi:10.1016/j.quascirev.2006.02.015

Benn, D.I., Lowe, J.J., Walker, M.J.C., 1992. Glacier response to climatic change during the Loch Lomond Stadial and early Flandrian: geomorphological and palynological evidence from the Isle of Skye, Scotland. Journal of Quaternary Science 7, 125-144.

Bennett, M.R., Boulton, G.S., 1993. Deglaciation of the Younger Dryas or Loch Lomond Stadial ice-field in the northern Highlands, Scotland. Journal of Quaternary Science 8, 133-145.

Bennett, M.R., Glasser, N.F., 1991. The glacial landforms of Glen Geusachan, Cairngorms: a reinterpretation. Scottish Geographical Magazine 107, 116-123.

Brooks, S.J., Birks, H.J.B., 2000. Chironomid-inferred Late-glacial air temperatures at Whitrig Bog, southeast Scotland. Journal of Quaternary Science 15, 759-764.

Clapperton, C.M., 1997. Greenland ice cores and North Atlantic sediments: implications for the last glaciation in Scotland. In: Gordon, J.E. (Ed.), Reflections of the ice age in Scotland: an update on Quaternary Studies. Scottish Association of Geography Teachers and Scottish Natural Heritage, Glasgow, 45-58.

Clark, C.D., 1997. Reconstructing the evolutionary dynamics of former ice sheets using multi-temporal evidence, remote sensing and GIS. Quaternary Science Reviews 16, 1067-1092.

Clark, C.D., Stokes, C.R., 2003. Palaeo-ice stream landsystem. In: Evans, D.J.A. (Ed.), Glacial Landsystems. Arnold, London, p204-227.

Colgan, P.M., Mickelson, D.M., Cutler, P.M., 2003. Ice-marginal terrestrial landsystems: southern Laurentide Ice Sheet margin. In: Evans, D.J.A. (Ed.), Glacial Landsystems. Arnold, London, p111-142.

Dansgaard, W., White, J.C., Johnsen, S.J., 1989. The abrupt termination of the Younger Dryas climate event. Nature 339, 532-534. 
Evans, D.J.A., 2003a. Glacial Landsystems. Arnold, London.

Evans, D.J.A., 2003b. Introduction to glacial landsystems. In: Evans, D.J.A. (Ed.), Glacial

Landsystems. Arnold, London, p1-11.

Evans, D.J.A., 2003c. Ice-marginal terrestrial landsystems: active temperate glacier margins. In:

Evans, D.J.A. (Ed.), Glacial Landsystems. Arnold, London, p12-43.

Evans, D.J.A., Rose, J. 2003. Croftamie. In: Classic Landforms of the Loch Lomond Area. p38-39. Geographical Association, Sheffield.

Evans, D.J.A., Twigg, D.R., 2002. The active temperate glacial landsystem: a model based on Breidamerkurjökull and Fjallsjökull, Iceland. Quaternary Science Reviews 21, 2143-2177.

Eyles, N., 1983. Glacial geology: a landsystems approach. In: Eyles, N. (Ed.), Glacial Geology. Pergamon, Oxford, p1-18.

Fitzsimons, S., 2003. Ice-marginal terrestrial landsystems: polar-continental glacier margins. In:

Evans, D.J.A. (Ed.), Glacial Landsystems. Arnold, London, p89-110.

Glasser, N.F., 1995. Modelling the effect of topography on ice sheet erosion, Scotland.

Geografiska Annaler 77A, 67-82.

Glasser, N.F., 1997. The dynamics of ice sheets and glaciers. In: Gordon, J.E. (Ed.), Reflections of the ice age in Scotland: an update on Quaternary Studies. Scottish Association of Geography Teachers and Scottish Natural Heritage, Glasgow, p37-44.

Glasser, N.F., Hambrey, M., 2003. Ice-marginal terrestrial landsystems:Svalbard polythermal glaciers. In: Evans, D.J.A. (Ed.), Glacial Landsystems. Arnold, London, p65-88.

Glasser, N.F., Siegert, M.J., 2002. Calculating basal temperatures in ice sheets: an Excel spreadsheet method. Earth Surface Processes and Landforms 27, 673-680.

Glasser, N.F., Jansson K.N., Harrison, S., Rivera, A., 2005. Geomorphological evidence for variations of the North Patagonian Icefield during the Holocene. Geomorphology, 263-277.

Golledge, N.R., Hubbard, A., 2005. Evaluating Younger Dryas glacier reconstructions in part of the Western Scottish Highlands: a combined empirical and theoretical approach. Boreas 34, 274-286.

Horsfield, B.R., 1983. The deglaciation pattern of the Western Grampians of Scotland. Unpublished Ph.D thesis. University of East Anglia.

Hubbard, A. 1999. High-resolution modeling of the advance of the Younger Dryas ice sheet and its climate in Scotland. Quaternary Research 52, 27-43.

Hulton, N., Sugden, D.E., 1997. Dynamics of mountain ice caps during glacial cycles: the case of Patagonia. Annals of Glaciology 24, 81-89.

Ives, J.D., Andrews, J.T., Barry, R.G., 1975. Growth and decay of the Laurentide Ice Sheet and 
comparisons with Fenno-Scandinavia. Naturwissenschaften 62, 118-125.

Jones, T., 1998. Empirical testing of Loch Lomond Stadial glacier limits derived from a

glaciological model for the Applecross Peninsula, Wester Ross, Scotland. Scottish Geographical

Magazine 114, 164-171.

Kleman, J. 1994. Preservation of landforms under ice sheets and ice caps. Geomorphology 9,

$19-32$.

Kovanen, D.J., Slaymaker, O., 2004. Glacial imprints of the Okanogan Lobe, southern margin of the Cordilleran Ice Sheet. Journal of Quaternary Science 19, 547-565.

Kerr, A., 1993. Topography, climate and ice masses: a review. Terra Nova 5, 332-342.

Lowe, J.J., Walker, M.J.C., 1976. Radiocarbon-dates and deglaciation of Rannoch Moor, Scotland. Nature 264, 632-633.

Lukas, S., 2005. Younger Dryas moraines in the NW Highlands of Scotland: genesis, significance and potential modern analogues. Unpublished Ph.D thesis, University of St. Andrews.

Manley, G., 1955. On the occurence of ice domes and permanently snow-covered summits.

Journal of Glaciology 2, 453-456.

Mitchell, W.A., 1994. Drumlins in ice sheet reconstructions, with reference to the western

Pennines, northern England. Sedimentary Geology 91, 313-331.

Nye, J.F., 1952. The mechanics of glacier flow. Journal of Glaciology 2, 82-93.

Ó Cofaigh, C., Evans, D.J.A., England, J. 2003. Ice-marginal terrestrial landsystems: sub-polar glacier margins of the Canadian and Greenland high Arctic. In: Evans, D.J.A. (Ed.), Glacial

Landsystems. Arnold, London, p44-64.

Ohmura, A., Kasser, P., Funk, M., 1992. Climate at the equilibrium line of glaciers. Journal of Glaciology 38, 397-411.

Paterson, W.S.B., 2000. The Physics of Glaciers. 3rd Edition. Pergamon, Oxford.

Payne, A., Sugden, D.E., 1990. Topography and ice sheet growth. Earth Surface Processes and Landforms 15, 625-639.

Porter, S.C., 2001. Snowline depression in the tropics during the Last Glaciation. Quaternary Science Reviews 20, 1067-1091.

Purves, R., Hulton, N.J., 2000. Experiments in linking regional climate, ice-sheet models and topography. Journal of Quaternary Science 15, 369-375.

Purves, R.S., Mackaness, W.A., Sugden, D.E., 1999. An approach to modelling the impact of snow drift on glaciation in the Cairngorm Mountains, Scotland. Journal of Quaternary Science $14,313-321$.

Rea, B.R., Evans, D.J.A., 2003. Plateau icefield landsystems. In: Evans, D.J.A. (Ed.), Glacial 
Landsystems. Arnold, London, p407-431.

Rea, B.R., Whalley, W.B., Evans, D.J.A., Gordon, J.E., McDougall, D.A., 1998. Plateau

icefields: geomorphology and dynamics. In: Owen, L.A. (Ed.), Mountain Glaciation. Quaternary

Proceedings 6, Wiley, Chichester, p35-54.

Schytt, V., 1967. A study of "ablation gradient". Geografiska Annaler 49A, 327-332.

Sissons, J.B., 1979. The Loch Lomond Stadial in the British Isles. Nature 280, 199-203.

Sissons, J.B., 1980. Palaeoclimatic inferences from Loch Lomond Advance glaciers. In: Lowe, J.

J., Gray, J. M. Robinson, J. E. (Eds.), Studies in the Lateglacial of North-west Europe, 31-43.

Pergamon, Oxford.

Sissons, J.B., Lowe, J.J., Thompson, K.S.R., Walker, M.J.C., 1973. Loch Lomond Readvance in the Grampian Highlands of Scotland. Nature 244, 75-77.

Stokes, C.R., Clark, C.D., 1999. Geomorphological criteria for identifying Pleistocene ice

streams. Annals of Glaciology 28, 67-74.

Sugden, D.E., John, B., 1976. Glaciers and Landscape. Arnold, London.

Sugden, D.E., Hulton, N.R.J., Purves, R.S., 2002. Modelling the inception of the Patagonian icesheet. Quaternary International 95-96, 55-64.

Sutherland, D.G., 1984. Modern glacier characteristics as a basis for inferring former climates with particular reference to the Loch Lomond Stadial. Quaternary Science Reviews 3, 291-309.

Thompson, K.S.R., 1972. The last glaciers of Western Perthshire. Unpublished Ph.D thesis. University of Edinburgh.

Thorp, P.W., 1981. A trimline method for defining the upper limit of Loch Lomond Advance glaciers: examples from the Loch Leven and Glen Coe areas. Scottish Journal of Geology 17, 49-64.

Thorp, P.W., 1984. The glacial geomorphology of part of the western Grampians of Scotland with especial reference to the limits of the Loch Lomond Advance. Unpublished Ph.D thesis, City of London Polytechnic.

Thorp, P.W., 1986. A mountain icefield of Loch Lomond Stadial age, western Grampians,

Scotland. Boreas 15, 83-97.

Thorp, P.W., 1987. Late Devensian ice sheet in the western Grampians, Scotland. Journal of Quaternary Science 2, 103-112.

Thorp, P.W., 1991a. The glaciation and glacial deposits of the western Grampians. In: Ehlers, J., Gibbard, P. L., Rose, J. (Eds.), Glacial Deposits in Great Britain and Ireland, Balkema, Rotterdam, p137-149.

Thorp, P.W., 1991b. Surface profiles and basal shear stresses of outlet glaciers from a 
Late-glacial mountain ice field in western Scotland. Journal of Glaciology 37, 77-88.

van der Wateren, F.M. 2003. Ice-marginal terrestrial landsystems: Southern Scandinavian Ice Sheet Margin. In: Evans, D.J.A. (Ed.), Glacial Landsystems. Arnold, London, p166-203.

Weertman, J., 1973. Creep of ice. In: Whalley, E., Jones, S.J., Gold, L.W., (Eds.), Physics and chemistry of ice. Royal Society of Canada, Ottawa, p320-337.

Witte, H.J.L., Coope, G.R., Lemdahl, G., Lowe, J.J., 1998. Regression coefficients of thermal gradients in northwestern Europe during the last glacial-Holocene transition using beetle MCR data. Journal of Quaternary Science 13, 435-445. 


\section{Figure captions}

Figure 1: A. Schematic representation of glacier evolution from 1) corrie glacier through 2) valley glacier, 3) mountain icefield, 4) ice cap into 5) ice sheet. Note the lateral expansion in addition to vertical thickening, and the changing ice flow directions that may occur as the ice shed becomes increasingly independent of topography. B. The bifurcation in ice-mass evolution that results from large and small temperature depressions, leading to unstable and stable ice sheets respectively (adapted from Payne \& Sugden, 1990). C \& D. Contrasting growth of ice masses on different topographies (redrawn from Payne \& Sugden, 1990).

Figure 2: The study area in western Scotland, showing generalized distribution of the key landsystem elements, localities described in the text and the approximate locations of detailed examples given in Figures 3 \& 4. Firn lines are interpolated from a grid built from the contours of Sissons $(1979,1980)$. Inset shows the location of the study area in Scotland, the extent of Younger Dryas glaciation (Sissons, 1980), and localities mentioned in the text beyond the study area. Scale given by $5 \mathrm{~km}$ British National Grid ticks (main map), and Lat / Long lines (inset). OS topography (C) Crown copyright. All rights reserved.

Figure 3: Examples of geomorphological and sedimentological elements of the ice cap landsystem: A \& B, topographically discordant moraines in Cononish Glen showing stillstand positions and intervening, more chaotic, recessional moraines; C \& D, bedded sand exhibiting sheath fold with southerly vergence, Coire Chailein; E \& F, glaciolacustrine delta concordant with topographic slope, Coire Earb. Note the gently sloping surface and steeper delta front. Orthorectified aerial photograph in (A) C) NERC, 2006, from original image (C) Royal Commission on the Ancient and Historical Monuments of Scotland (RCAHMS). Photos (C) \& (E) BGS registered photographs, (C) NERC, 2006.

Figure 4: Relief-shaded digital terrain model (DTM) of the plateau area south of the Ben Lui Beinn Dubhchraig massif, showing streamlined bedrock, remoulded (barchanoid) ridges, and superimposed bedforms composed of subglacial diamicton. Thick arrows indicate direction of former ice flow via outlet valleys, based on the orientation of the bedforms and the direction of local erratic carry. DTM built from Intermap Technologies NEXTMap $1.5 \mathrm{~m}$ resolution topographic data. Scale given by $5 \mathrm{~km}$ British National Grid lines at $1 \mathrm{~km}$ intervals.

Figure 5: Palaeoglaciological reconstruction of the Younger Dryas ice cap in the study area, based on the field data summarized in Figure 2. The hillshaded digital terrain model illustrating bed topography and nunataks was built from Intermap Technologies NEXTMap $1.5 \mathrm{~m}$ resolution 
topographic data. Lines A, B, and C locate the cross-sections shown in Figure 7. Nunataks probably supported snow cover and may have hosted thin, immobile ice not represented here. Scale given by $5 \mathrm{~km}$ British National Grid ticks.

Figure 6: Curve describing the inverse relationship between summit breadth and height above ELA required for snow accumulation proposed by Manley (1955), showing the characteristics of Ben More (BM), Stob Binnein (SB), Cruach Ardrain (CA), Beinn Tulaichean (BT), An Caisteal (AC), Beinn a' Chroin (BaC) and Beinn Chabhair (BC). The summits of all except BT and BC could theoretically support snow accumulation. Dashed lines indicate the broad classification of summit accumulation types inferred by Manley for different summit breadths.

Figure 7: Cross-sections showing topography and reconstructed ice surfaces from A., the southern margin of Rannoch Moor at Black Mount to Loch Lomond; B., Black Mount to Glen

Orchy; and C., Black Mount to Glen Lochay. Surfaces are interpolated from grids of ice surface and topography using ArcGIS 9.0. Dashed lines indicate ice surfaces extrapolated from the proscribed maximum ice heights of Thorp $(1984,1986)$ in the north of the area. Light shading denotes nunataks under the Thorp model; dark shading represents nunataks under the new model proposed here. Note the difference in the degree of topographic control in each transect.

Figure 8: Calculated ice extent in the study area (white areas), based on grid subtraction of topography from the reconstructed ice surface grid in Figure 5. Panels show, A: ice extent at Younger Dryas maximum, B: the impact of $100 \mathrm{~m}$ ice thinning and C: the impact of $200 \mathrm{~m}$ ice thinning. Note the result of increasing topographic control on ice flow directions, and the more rapid recession of eastern margins than those in the west. This simple decay scenario does not, however, account for local ice surface variability and does not differentiate between active and stagnant ice. Scale given by British National Grid ticks at $10 \mathrm{~km}$ intervals.

\section{Table captions}

Table 1: Summary of generalised physical, geomorphological and sedimentological characteristics - landsystem elements - for a range of ice masses of different scales.

Table 2: Character, presence or absence of each of the eight key landsystem elements in the study area. 


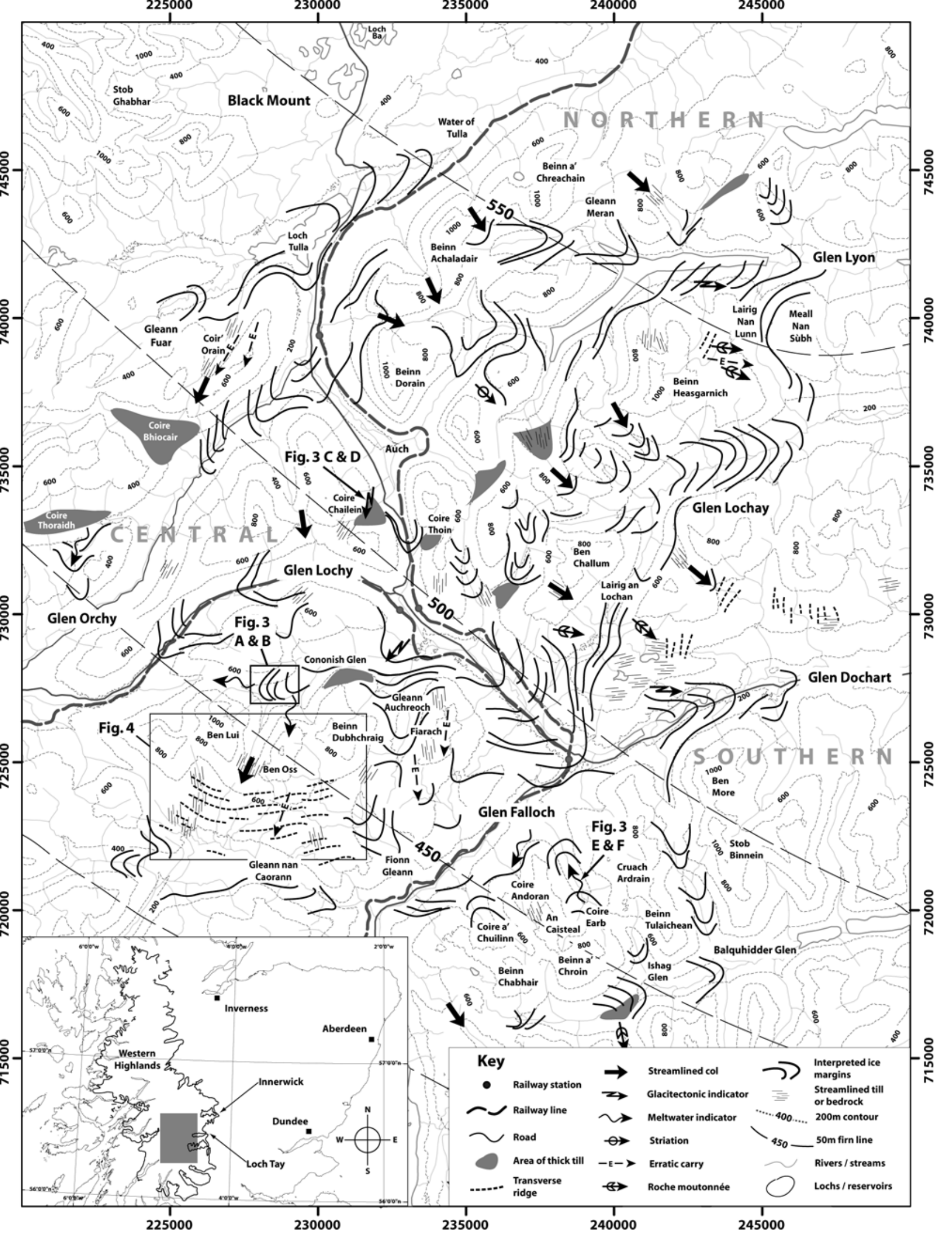




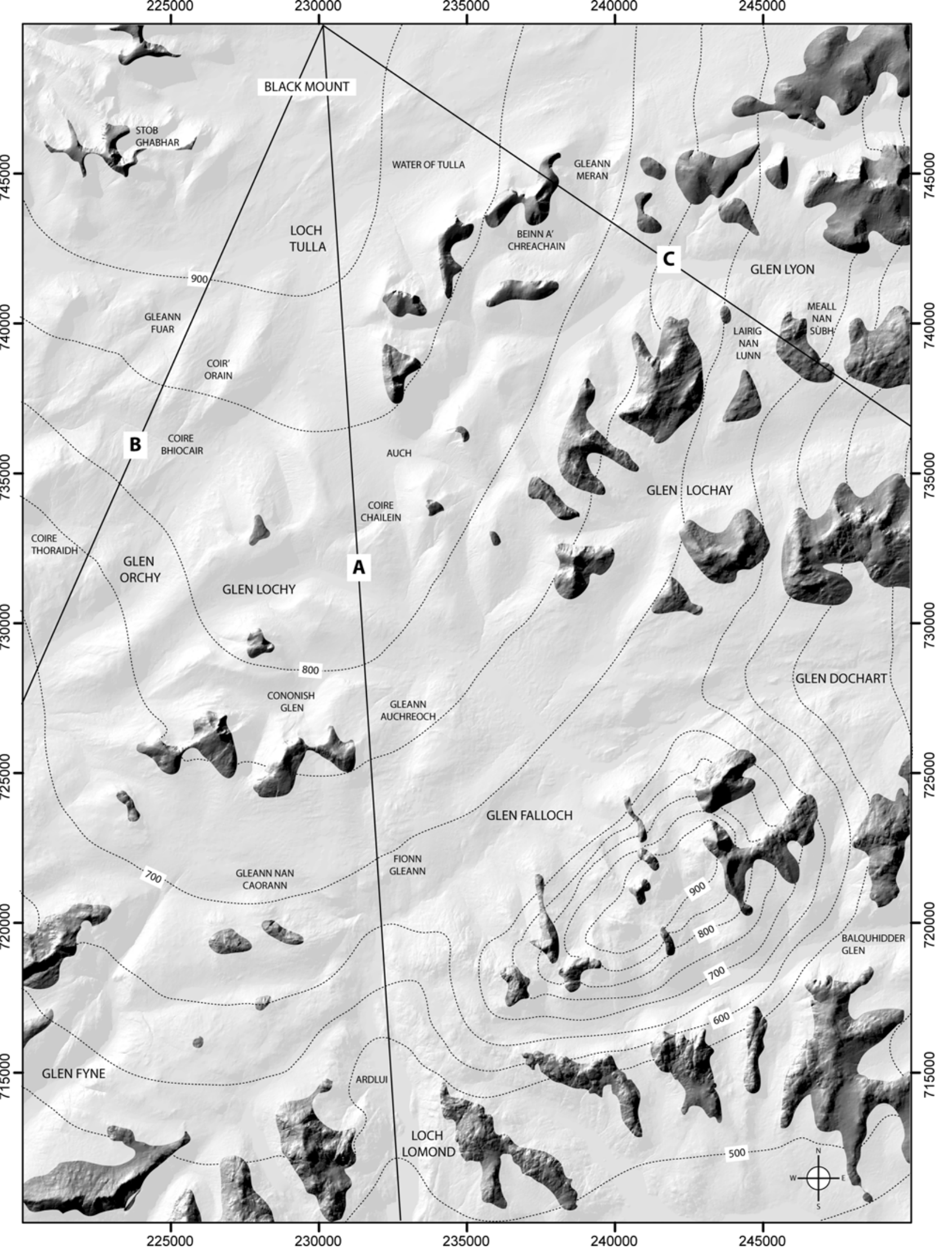




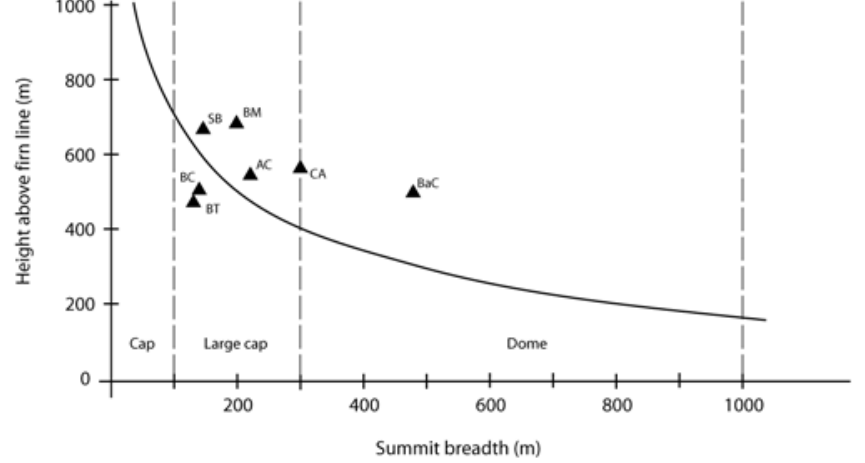



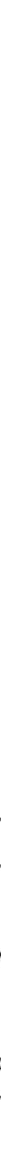


\begin{tabular}{|c|c|c|c|c|c|}
\hline \multirow{2}{*}{ Lands ys tem elements } & \multicolumn{5}{|c|}{ Decreasing ice thickness / increasing topographic control } \\
\hline & Ice sheet & Icecap & Icefield & Valley glacier & Corrie glacier \\
\hline $\begin{array}{l}\text { Scale (approximate } \\
\text { order of magnitude only) }\end{array}$ & $>10000 \mathrm{~km}^{2}$ & $>1000 \mathrm{~km}^{2}$ & $>100 \mathrm{~km}^{2}$ & $>10 \mathrm{~km}^{2}$ & $<10 \mathrm{~km}^{2}$ \\
\hline Geometry & $\begin{array}{l}\text { Domed accumulation area, } \\
\text { with out let lobes of variable } \\
\text { gradient (particularly where } \\
\text { marine terminating). }\end{array}$ & $\begin{array}{l}\text { Mainly domed accumulation } \\
\text { area, with relatively steep } \\
\text { outlet glaciers. }\end{array}$ & $\begin{array}{l}\text { Non-domed, approximately } \\
\text { level accumulation area with } \\
\text { low surface-slope outlet } \\
\text { glaciers. }\end{array}$ & $\begin{array}{l}\text { Elongate, with variable ice } \\
\text { surface slope from } \\
\text { accumulation area to margin. }\end{array}$ & $\begin{array}{l}\text { Sub-circular, steep-sided, } \\
\text { generally concavo-convex } \\
\text { surface profile. }\end{array}$ \\
\hline $\begin{array}{l}\text { Ice marginal landforms } \\
\text { and sediments. }\end{array}$ & $\begin{array}{l}\text { Often offshore, at formerly } \\
\text { grounded or calving margins. }\end{array}$ & $\begin{array}{l}\text { Typically terrestrial, often in } \\
\text { lowland areas. Deglacial } \\
\text { features may be discordant } \\
\text { with local topographic slope. }\end{array}$ & $\begin{array}{l}\text { Typically terrestrial, often in } \\
\text { lowland areas. Deglacial } \\
\text { features generally concordant } \\
\text { with local topographic slope. }\end{array}$ & $\begin{array}{l}\text { Typically terrestrial, often in } \\
\text { upland areas or fringes of } \\
\text { lowlands. }\end{array}$ & $\begin{array}{l}\text { Terrestrial assemblages in well } \\
\text { defined generally high-altitude } \\
\text { topographic hollows. }\end{array}$ \\
\hline $\begin{array}{l}\text { Subglacial sediment } \\
\text { deposition. }\end{array}$ & $\begin{array}{l}\text { Often complete removal of } \\
\text { pre-existing sediments in } \\
\text { upland areas. Ubiquitous } \\
\text { deposition of subglacial till. }\end{array}$ & $\begin{array}{l}\text { Asymmetric deposition of till } \\
\text { on valley sides. Accumulation } \\
\text { of thick sediment sequences in } \\
\text { valley floors, preservation of } \\
\text { pre-existing deposits. }\end{array}$ & $\begin{array}{l}\text { Erosion of pre-exisitng valley- } \\
\text { floor deposits. Symmetrical } \\
\text { valley-side till deposition. }\end{array}$ & $\begin{array}{l}\text { Erosion of pre-existing valley- } \\
\text { floor deposits. Symmetrical } \\
\text { valley-side till deposition. }\end{array}$ & \begin{tabular}{|l|} 
Erosion of pre-exisitng \\
sediments, limited subglacial \\
deposition, often bouldery \\
supraglacial and ice-marginal \\
deposits.
\end{tabular} \\
\hline $\begin{array}{l}\text { High-level cols and } \\
\text { interfluves }\end{array}$ & $\begin{array}{l}\text { Generally always overtopped } \\
\text { and streamlined. }\end{array}$ & $\begin{array}{l}\text { Often overtopped and } \\
\text { streamlined, particularly in } \\
\text { central areas. }\end{array}$ & $\begin{array}{l}\text { Only streamlined at low } \\
\text { altitudes and in central areas. }\end{array}$ & $\begin{array}{l}\text { Rarely overtopped unless very } \\
\text { low, more often act as barriers } \\
\text { to flow. }\end{array}$ & Not applicable. \\
\hline $\begin{array}{l}\text { Pattern of local iceflow } \\
\text { shown by kinematic } \\
\text { indicators. }\end{array}$ & $\begin{array}{l}\text { Determined by ice surface } \\
\text { slope, irrespective of } \\
\text { topographic slope. }\end{array}$ & $\begin{array}{l}\text { Determined by ice surface } \\
\text { slope, irrespective of } \\
\text { topographic slope. }\end{array}$ & \begin{tabular}{|l} 
Typically parallel to major \\
valleys and topographic lows. \\
Generally follows slope of \\
underlying land surface. \\
\end{tabular} & $\begin{array}{l}\text { Always valley-parallel, } \\
\text { following topographic slope. }\end{array}$ & \begin{tabular}{|l|} 
Outward from the cirque \\
backwall along lines of \\
steepest topographic gradient.
\end{tabular} \\
\hline $\begin{array}{l}\text { Direction offlow of ice- } \\
\text { marginal drainage. }\end{array}$ & $\begin{array}{l}\text { Away from ice margins either } \\
\text { with or against topography. }\end{array}$ & $\begin{array}{l}\text { Away from ice margins either } \\
\text { with or against topography. }\end{array}$ & $\begin{array}{l}\text { Away from ice margins } \\
\text { generally following } \\
\text { topography. }\end{array}$ & $\begin{array}{l}\text { Away from ice margins always } \\
\text { following topography. }\end{array}$ & $\begin{array}{l}\text { Away from ice margins always } \\
\text { following topography. }\end{array}$ \\
\hline $\begin{array}{l}\text { Style of palaeo-iceflow of } \\
\text { whole ice mass }\end{array}$ & $\begin{array}{l}\text { Radial from a central dome or } \\
\text { iceshed. }\end{array}$ & $\begin{array}{l}\text { Predominantly radial from a } \\
\text { central or local dome, or } \\
\text { iceshed. }\end{array}$ & $\begin{array}{l}\text { Only radial where unconfined, } \\
\text { otherwise generally directed } \\
\text { by major topographic } \\
\text { features. }\end{array}$ & $\begin{array}{l}\text { Always valley-parallel, } \\
\text { following topographic slope. }\end{array}$ & \begin{tabular}{|l|} 
Out ward from the cirque \\
backwall along lines of \\
steepest topographic gradient.
\end{tabular} \\
\hline
\end{tabular}

Table 1. 


\begin{tabular}{|l|c|c|c|}
\hline \multicolumn{1}{|c|}{ Lands ystem element(s) } & Northern Sector & Central sector & Southern sector \\
\hline $\begin{array}{l}\text { Scale (approximate order of } \\
\text { magnitude only) }\end{array}$ & $>1000 \mathrm{KM}^{2}$ & $>1000 \mathrm{KM}^{2}$ & $>10 \mathrm{KM}^{2}$ \\
\hline Geometry & $\begin{array}{c}\text { CENTRAL DOME \& } \\
\text { OUTLET GLACIERS }\end{array}$ & $\begin{array}{c}\text { CENTRAL DOME \& } \\
\text { OUTLET GLACIERS }\end{array}$ & $\begin{array}{c}\text { VALLEY GLACIERS SOURCED } \\
\text { FROM SUMMITS }\end{array}$ \\
\hline $\begin{array}{l}\text { Topographically discordant ice- } \\
\text { marginal landforms }\end{array}$ & YES & YES & NO \\
\hline $\begin{array}{l}\text { Localised thick till accumulations, } \\
\text { preserved sequences, asymmetric } \\
\text { valley-side till cover }\end{array}$ & YES & YES \\
\hline Streamlined high-level cols & YES & YES & YES \\
\hline $\begin{array}{l}\text { Counter-topographic palaeo-iceflow } \\
\text { indicators }\end{array}$ & YES & YES & NO \\
\hline $\begin{array}{l}\text { Counter-topographic flow of ice- } \\
\text { contact fan sediments }\end{array}$ & YES & YES & NO \\
\hline Collective evidence of radial ice-flow & REGIONAL & REGIONAL & LOCAL \\
\hline
\end{tabular}

Table 2. 